\title{
Poisoning by Poiretia punctata in cattle and sheep ${ }^{1}$
}

\author{
Eduardo M. Nascimento ${ }^{2 *}$, Rosane M.T. Medeiros ${ }^{2}$, Stephen T. Lee ${ }^{3}$ \\ and Franklin Riet-Correa ${ }^{2}$
}

\begin{abstract}
Nascimento E.M., Medeiros R.M.T., Lee S.T. \& Riet-Correa F. 2014. Poisoning by Poiretia punctata in cattle and sheep. Pesquisa Veterinária Brasileira 34(10):963-966. Setor de Patologia Animal, Faculdade de Veterinária, Universidade Federal de Campina Grande, Av. Universitária s/n, Patos, PB 58708-110, Brazil. E-mail: eduardoaquario@hotmail.com

Poiretia punctata (Willd.) Desv. was associated with cattle and sheep poisoning on nine farms in the State of Sergipe, northeastern Brazil. The animals were found dead or died later after showing clinical signs for up to 18 hours. Two sheep that ingested $40 \mathrm{~g} / \mathrm{kg}$ body weight $(\mathrm{g} / \mathrm{kg})$ of fresh P. punctata died three and eight hours after ingestion, respectively. Another sheep that ingested $40 \mathrm{~g} / \mathrm{kg}$ five days after plant collection showed mild clinical signs and recovered after 24 hours. Two sheep that received $20 \mathrm{~g} / \mathrm{kg}$ and another that ingested three daily doses of $20 \mathrm{~g} / \mathrm{kg}$ showed clinical signs, but recovered. Two cattle that ingested $20 \mathrm{~g} / \mathrm{kg}$ of the fresh plant exhibited clinical signs and recovered. The clinical observations of poisoning were depression, ataxia, loss of equilibrium, broad-based stance, head down, falls, mandibular trismus, opisthotonous, nystagmus, and recumbence. Significant gross and histologic lesions were not observed. Samples of P. punctata were analyzed for nitrates, cyanogenic glycosides, and sodium monofluouracetate with negative results. It is concluded that $P$. punctata is a toxic plant that caused death in cattle and sheep in the State of Sergipe.
\end{abstract}

INDEX TERMS: Poisonous plants, Poiretia punctata, plant poisoning, sheep, cattle.

RESUMO.- [Intoxicação por Poiretia punctata em bovinos e ovinos.] Poiretia punctata (Willd.) Desv. foi associada a intoxicações em bovinos e ovinos em nove fazendas no estado de Sergipe, nordeste do Brasil. Os animais eram encontrados mortos ou morreram após apresentar sinais clínicos com evolução de até 18 horas. Dois ovinos que ingeriram P. punctata, fresca, na dose de $40 \mathrm{~g} / \mathrm{kg}$ de peso corporal $(\mathrm{g} / \mathrm{kg})$ morreram após a ingestão da planta em três e oito horas, respectivamente. Outro ovino que ingeriu a planta coletada cinco dias antes de ser oferecida ao animal na dose de $40 \mathrm{~g} / \mathrm{kg}$ apresentou sinais clínicos leves e se recuperou depois de 24 horas. Dois ovinos que receberam $20 \mathrm{~g} / \mathrm{kg}$ e

\footnotetext{
${ }^{1}$ Received on August 11, 2014.

Accepted for publication on August 28, 2014.

Parte da Dissertação de Mestrado do primeiro autor, Programa de Pós-Graduação em Medicina Veterinária, Universidade Federal de Campina Grande (UFCG), Av. Universitária s/n, Bairro Santa Cecília, Patos, PB 58708-110, Brazil.

${ }^{2}$ Hospital Veterinário, Centro de Saúde e Tecnologia Rural (STR), UFCG, Patos, PB 58708-110, Brazil. *Corresponding author: eduardoaquario@ hotmail.com

${ }^{3}$ Poisonous Plant Research Laboratory, Agricultural Research Service, United States Department of Agriculture, 1150 E. 1400 N., Logan, Utah 84341, USA.
}

outro que ingeriu, durante três dias consecutivos, doses de $20 \mathrm{~g} / \mathrm{kg}$ apresentaram sinais clínicos leves e se recuperaram. Dois bovinos que ingeriram a planta fresca, na dose de $20 \mathrm{~g} / \mathrm{kg}$ apresentaram sinais clínicos e se recuperaram. As observações clínicas da intoxicação foram depressão, ataxia, perda de equilíbrio, postura de base ampla, cabeça baixa, quedas, trismo mandibular, opistótono, nistagmo e decúbito. Não foram observadas lesões macroscópicas nem histológicas de significância. Amostras de P. punctata foram analisadas para nitratos, glicosídeos cianogênicos, e monofluoracetato sódio com resultados negativos. Conclui-se que P. punctata é uma planta tóxica que causa morte de bovinos e ovinos no estado de Sergipe.

TERMOS DE INDEXAÇÃO: Plantas tóxicas, Poiretia punctata, intoxicação por plantas, ovinos, bovinos.

\section{INTRODUCTION}

Poiretia punctata (Willd.) Desv. of the Fabaceae family (Fig.1) occurs in the Brazilian States of Ceará, Pernambuco, Paraíba, Bahia, Minas Gerais, Rio de Janeiro, São Paulo, and Goiás and occupies pastures, disturbed areas, forests, hillsides, and along roadsides (Muller 1984).

In southern Sergipe, a plant identified as P. punctata has 

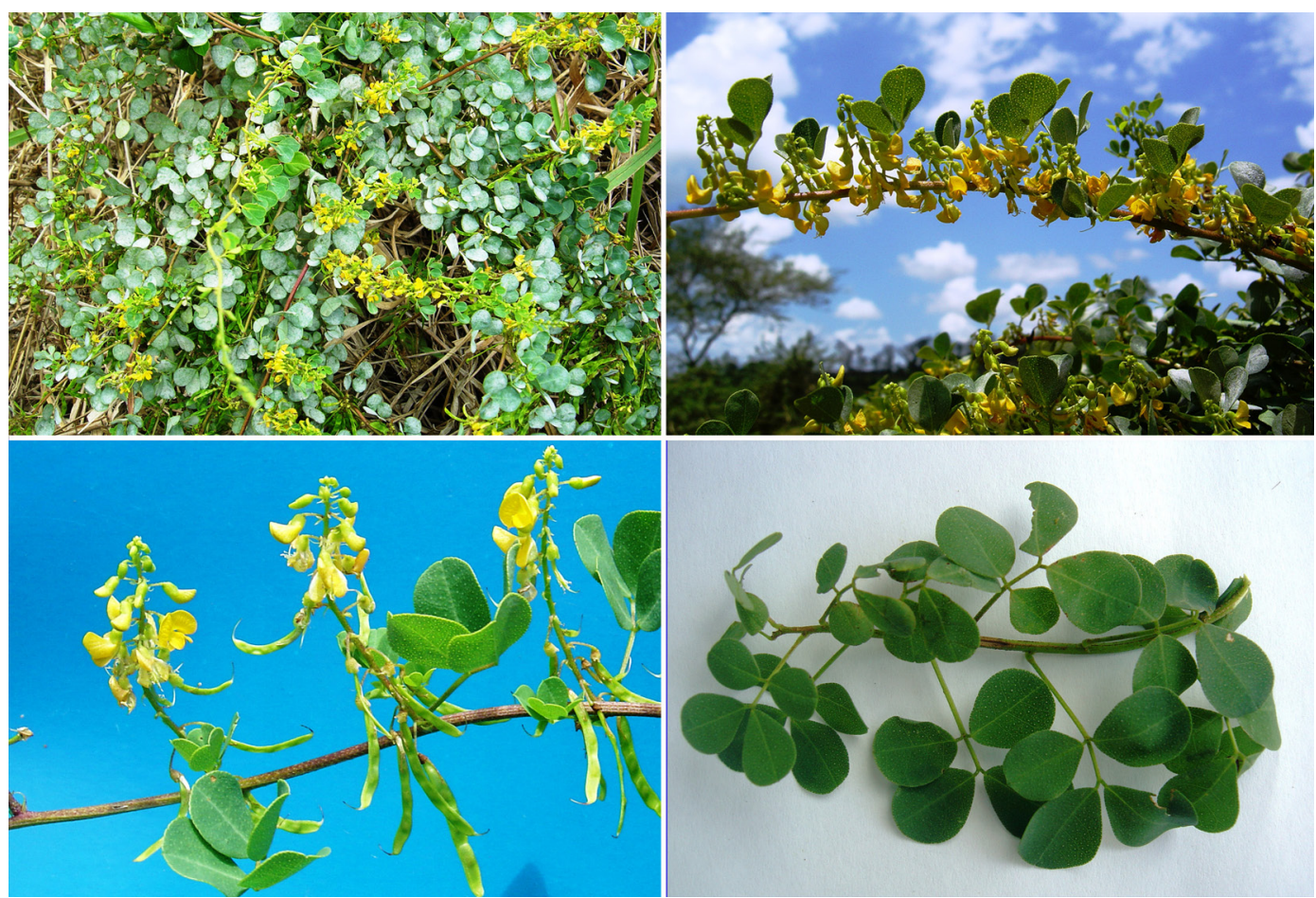

Fig.1. Poiretia punctata in the municipality of Arauá, Sergipe, northeastern Brazil.

been reported by livestock owners as a plant that causes acute clinical signs and death in sheep and cattle. Farms in the municipality of Arauá, Sergipe, were visited to investigate the poisoning of sheep and cattle by P. punctata. In addition, sheep and cattle were fed $P$. punctata under controlled conditions to reproduce the poisoning.

\section{MATERIALS AND METHODS}

Pressed plant samples were identified by Dr. Odaci de Oliveira, Federal Rural University of the Semiarid, Mossoró, Rio Grande do Norte, Brazil.

The presence of nitrates or cyanogenic glycosides was evaluated in fresh samples of Poiretia punctata using the diphenylamine and the picrosodic paper tests (Riet-Correa et al. 1993), respectively. Two dried samples of the whole plant were sent to the Poisonous Plant Research Laboratory in Logan, USA, to be analyzed for the presence of sodium monofluoracetate by HPLC-APCI-MS (Lee et al. 2012)

Epidemiological data were obtained by visits to the farms and interviews with farmers in their respective properties. For the experimental reproduction of the poisoning P. punctata was collected in a farm in the County of Arauá (S1 ${ }^{\circ} 14^{\prime}$ '58.81" and W37 $\left.37^{\prime} 50.11^{\prime \prime}\right)$, State of Sergipe. The experiments were performed on a farm near the plant collection site and at the Veterinary Hospital in Patos, Paraíba. The plant was experimentally administered to six, 4-20 month old, male and female crossbred hair sheep, weighing 8-20 kg and to two crossbred calves weighing 55 and $60 \mathrm{~kg}$. Three sheep and one calf were used as controls. Administered doses, body weight of the animals and time elapsed from plant collection to administration are shown in Table 1 . The plant was collected in the pasture and transported in nylon bags. The leaves, flowers and pods with seeds were manually separated from branches and were orally administered by repeatedly putting small amounts into the mouths of the animals.

Heart rates, respiratory and ruminal movements, and rectal temperature were determined in each experimental animal befo- re the start of the experiment and every hour after plant ingestion. In Sheep 5, 6, and 9 serum samples were collected by jugular venipuncture into vacutainer tubes with and without anticoagulant before plant administration and during the observation of clinical signs. Urine samples were also collected at the same time. Hemogram, urinalysis and determination of serum activities of creatine phosphokinase (CPK), aspartate aminotransferase (AST) and gamma glutamyltransferase(GGT) and serum urea and creatinine concentrations were measured in accordance with Thrall et al. (2012).

The sheep that died were necropsied. Samples of organs of abdominal and thoracic cavities, and central nervous system were collected, fixed in $10 \%$ formalin, processed routinely by embedding in paraffin and stained with hematoxylin-eosin for histological examination. All animal procedures were approved by the Bioethics Committee at the Federal University of Campina Grande, Patos, Paraiba (activity CEP 69-2013), and performed under veterinary supervision.

\section{RESULTS}

The plant reported by the livestock owner as causing the poisoning was identified as Poiretia punctata (Willd.) Desv. A voucher specimen of the plant was authenticated and deposited in the Centro de Saúde e Tecnologia Rural Herbarium - CSTR (HCSTR 3987).

\section{Spontaneous poisoning}

Death of livestock associated with the ingestion of $P$. punctata was reported by livestock owners from nine different farms. In seven of those farms the death of cattle or sheep associated with the consumption of the plant was sporadic. In two farms, outbreak of the disease caused death of several animals in a short period of time. In Farm 4, in a three month period (March to May 2012), 19 of 54 cattle grazing in a native pasture exhibited clinical signs, and 10 
Table 1. Experimental poisoning by Poiretia punctata in sheep and cattle. Animal weights, dose of the plant administered, time between collection and administration, clinical signs, onset of clinical signs and outcome of the poisoning

\begin{tabular}{|c|c|c|c|c|c|c|}
\hline Animal & $\begin{array}{l}\text { Weight } \\
\text { (kg) }\end{array}$ & $\begin{array}{c}\text { Dose } \\
\text { (g/kg) }\end{array}$ & $\begin{array}{l}\text { Time from collection } \\
\text { to administration }\end{array}$ & $\begin{array}{l}\text { Time from dosing } \\
\text { to first signs }\end{array}$ & $\begin{array}{l}\text { Clinical } \\
\text { signs }\end{array}$ & Outcome \\
\hline Sheep 1 & 8 & Single (40) & 5days & $1 \mathrm{~h}$ & Mild & Recovered in 24 hours \\
\hline Sheep 2 & 15 & Single (40) & $1 \mathrm{~h}$ & $1.5 \mathrm{~h}$ & Severe & Death in 3 hours \\
\hline Sheep 3 & 22 & Single (20) & $1 \mathrm{~h}$ & $1.5 \mathrm{~h}$ & Mild & Recovered in 24 hours \\
\hline Sheep 4 & 20 & $\begin{array}{l}3 \text { doses }(20) \\
\text { every } 24 \mathrm{hs}\end{array}$ & $1 \mathrm{~h}$ & $1.5 \mathrm{~h}$ & Mild & Recovered in 24 hours \\
\hline Sheep 5 & 18 & Single (20) & $22 \mathrm{~h}$ & $2 \mathrm{~h}$ & Mild & Recovered in 24 hours \\
\hline Sheep 6 & 15 & Single (40) & $48 \mathrm{~h}$ & $40 \mathrm{~min}$ & Severe & Death in 8 hours \\
\hline Sheep 7 & 19 & Control & - & - & Absent & - \\
\hline Sheep 8 & 21 & Control & - & - & Absent & - \\
\hline Shepp 9 & 14 & Control & - & - & Absent & - \\
\hline Calf 1 & 55 & Single (20) & $1 \mathrm{~h}$ & $1 \mathrm{~h}$ & Mild & Recovered in 24 hours \\
\hline Calf 2 & 70 & Single (20) & $1 \mathrm{~h}$ & $1 \mathrm{~h}$ & Mild & Recovered in 24 hours \\
\hline Cattle 3 & 90 & Control & - & - & Absent & - \\
\hline
\end{tabular}

died and 9 recovered. From the 10 animals that died, six were found dead in the pasture, two were in permanent sternal recumbence and two showed a staggering gait and died 3-18 hours after first observation of clinical signs. The nine animals that recovered showed apathy, isolation from the herd and reluctance to move. They remained sternally or laterally recumbent for long periods. They eventually recovered 20 to 24 hours after the first observation of clinical signs.

In Farm 9, the livestock owner reported the death of nine adult sheep from a flock of 68 of different ages. The animals were grazing in native pastures during the day and were housed overnight in pens. The total area of the farm was approximately 400 hectares divided into five paddocks. When the flock was grazing in a paddock of approximately 32 hectares, nine sheep did not return to the pens and were found dead in the next morning. Poiretia punctata was found in different amounts in all pastures inspected. The poisoning occurred in native pastures during the dry season, when there is shortage of high quality forage and $P$. punctata is still green. During the three-year period (20102012), 31 cattle and 14 sheep had their deaths attributed to poisoning by P. punctata in nine farms surveyed. Some livestock owners reported that they occasionally opened the rumen of the dead animals and found the presence of $P$. punctata in reasonable quantities in the rumen contents. Livestock owners reported that they have hand pulled $P$. punctata to remove it from their land to avoid livestock deaths from the plant.

The diphenylamine and the picrosodic paper tests were negative for the presence of nitrite and hydrogen cyanide, respectively. MFA was not detected in any of the samples analyzed.

\section{Experimental poisoning}

The observation of clinical signs in experimental sheep and cattle and the outcome of the poisoning are shown in Table 1. Sheep 1, 3, 4, and 5, which recovered, showed anorexia, reduced ruminal movements, apathy, incoordination, and loss of balance. Sheep 2 and 6, which died, showed anorexia, reduced ruminal movements, apathy, staggering gait, loss of balance, ataxia, broad-based stance, and head down

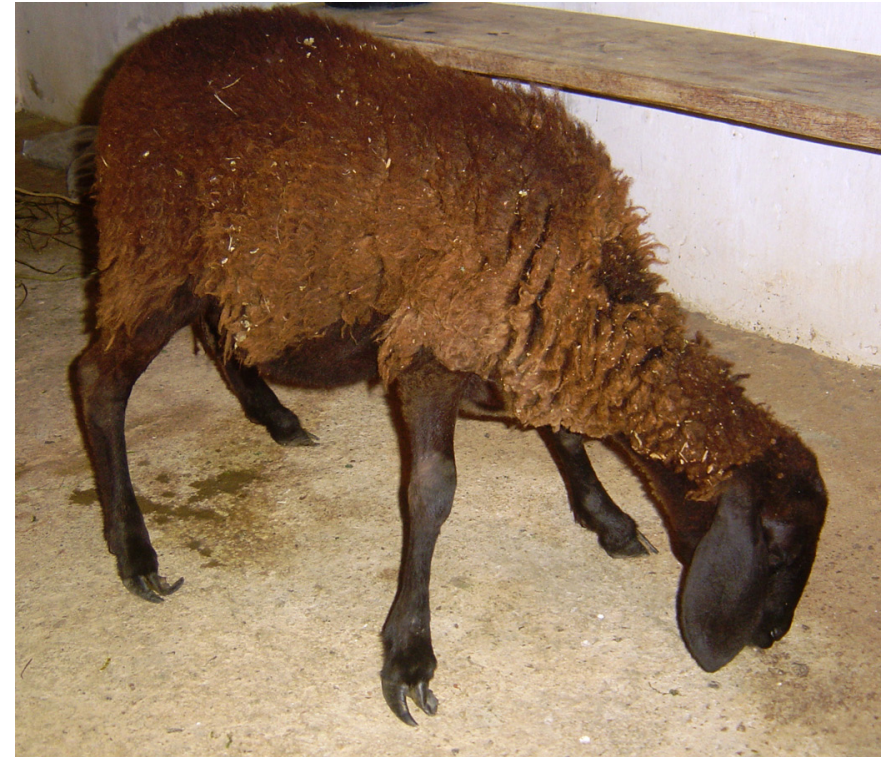

Fig.2. Sheep 2, experimentally poisoned by Poiretia punctata showing a broad-based stance and head down with marked depression.

(Fig.2). Falls, distended jugular vein, mandibular trismus, opisthotonous, and nystagmus were also observed. The condition progressed to sternal recumbence, leading to lateral recumbence and pedaling movements followed by death. No clinical signs were observed in Sheep 7, 8 and 9 (controls). Calves 1 and 2 showed apathy and anorexia. The animals often remained in sternal or laterally recumbency, looking to one side for several minutes. Calf 3 (control) showed no signs.

There were no significant changes observed in urinalysis, complete blood count, serum activities of AST, GGT and $\mathrm{CPK}$ and serum urea and creatinine. No significant changes were observed during the necropsies or upon histologic examination of the various tissues.

\section{DISCUSSION}

The presence of Poiretia punctata in all farms visited and the experimental reproduction of the poisoning in sheep and cattle with clinical signs and a clinical manifestation 
period similar to those mentioned by the farmers confirm that $P$. punctata is a toxic plant to cattle and sheep in the State of Sergipe.

The intoxication is acute and clinical signs suggest that it is a plant that primarily affects the nervous system. In some aspects, the clinical signs are similar to those caused by plants that contain MFA, including Amorimia rigida, Amorimia septentrionalis, Amorimia exotropica, Palicourea marcgravii and Palicourea aenofusca (Lee et al. 2012, Tokarnia et al. 2012), but the absence of MFA in plant samples that caused death when dosed to experimental animals eliminates this possibility. The fresh plant was also negative for the presence of nitrates and cyanogenic glycosides. The poisoning by those substances also cause clinical signs similar to those observed in P. punctata poisoning, but plants containing nitrates or cyanogenic glycosides have to be eaten in large amounts in a short period of time, whereas P. puncta$t a$ was toxic at a relative low dose of $20 \mathrm{~g} / \mathrm{kg}$ bw. The lack of gross or microscopic lesions suggests insufficient time for tissue damage to appear, and that further investigation may uncover a biochemical mechanism for the toxicity.

The diagnosis of the poisoning should be based on the presence of the plant and the occurrence of acute signs in the absence of gross and histological lesions. Besides the poisonings by plants containing MFA, nitrates and nitrites, and cyanogenic glycosides the differential diagnosis should considerer other acute diseases, including infections by $\mathrm{Ba}$ cillus anthracis (anthrax), Clostridium chauvoei (black leg), Clostridium novyitype D (bacillary hemoglobinuria), and babesiosis caused by Babesia argentina (tick fever).

Presently, the only way to prevent livestock poisoning by $P$. punctata is to not allow access to the plant. The effectiveness of current measures to remove the plants such as hand pulling or the use herbicides is not known. Further studies are needed to determine the toxic compound of the plant, which may allow the establishment of appropriate control measures.

Acknowledgements.- This work was supported by National Institute for Science and Technology forthe Control of Plant Poisonings, CNPq, grant 573534/2008-0.

\section{REFERENCES}

Lee S.T., Cook D., Riet-Correa F., Pfister J.A., Anderson W.R., Lima F.G. \& Gardner D. 2012. Detection of monofluoracetate in Palicourea and Amorimia species. Toxicon 60:791-796.

Muller C. 1984. Revisão taxonômica do gênero Poiretia Vent. (Leguminosae) para o Brasil. Master Dissertation, State University of Campinas, Campinas, SP. 146p.

Tokarnia C.H., Brito M.F., Barbosa J.D., Peixoto P.V. \& Döbereiner J. 2012. Plantas Tóxicas do Brasil. Editora Helianthus, Rio de Janeiro. 586p.

Thrall M.A., Weiser G., Alisson R. \& Campbel T.W. 2012. Veterinary and Clinical Chemistry. $2^{\text {nd }}$ ed. Wiley-Blacwell, Oxford. 762p. 